Journal of American Studies, 55 (202 I), 2, 387-4I7

(C) Cambridge University Press and British Association for American Studies 2020. This is an Open Access article, distributed under the terms of the Creative Commons Attribution licence (http://creativecommons.org/licenses/by/4.0/), which permits unrestricted re-use, distribution, and reproduction in any medium, provided the original work is properly cited. doi:10.1017/S0021875820000742 First published online 20 August 2020

\title{
"He Was Shot because America Will Not Give Up on Racism": Martin Luther King Jr. and the African American Civil Rights Movement in British Schools
}

\author{
MEGAN HUNT, BENJAMIN HOUSTON, BRIAN WARD \\ AND NICK MEGORAN
}

This article examines how Martin Luther King Jr. and the movement with which he is often synonymous are taught in UK schools, as well as the consequences of that teaching for twenty-first-century understandings of Britain's racial past and present. The UK's King-centric approach to teaching the civil rights movement has much in common with that in the US, including an inattention to its transnational coordinates. However, these shared (mis) representations have different histories, are deployed to different ends, and have different consequences. In the UK, study of the African American freedom struggle often happens in the absence of, and almost as a surrogate for, engagement with the histories of Britain's own racial minorities and imperial past. In short, emphasis on the apparent singularity of US race relations and the achievements of the mid-twentieth-century African American

Megan Hunt, School of History, Classics \& Archaeology, the University of Edinburgh. Email: megan.hunt@ed.ac.uk. Benjamin Houston, School of History, Classics and Archaeology, Newcastle University. Email: ben.houston@ncl.ac.uk. Brian Ward, Humanities Department, Northumbria University. Email: brian.ward@northumbria.ac.uk. Nick Megoran, School of Geography, Politics \& Sociology, Newcastle University. Email: nick.megoran@ncl.ac.uk. The quotation in the title is taken from an anonymous survey of final-year undergraduate students beginning modules on the African American freedom struggle at two universities in the North East of England in 2016. This response was to the question "In your own words, how would you summarize [MLK's] life and career?" Students taking the courses were drawn from American studies, history, history and English, and history and politics degree programmes. 
freedom struggle facilitates cultural amnesia regarding the historic and continuing significance of race and racism in the UK. In light of the Windrush scandal and the damning 2018 Royal Historical Society report on "Race, Ethnicity and Equality in UK History," this article argues both for better, more nuanced and more relevant teaching of King and the freedom struggle in British schools, and for much greater attention to black British history in its own right.

Writing to the Maroon Tiger as a Morehouse College student in 1947, Martin Luther King Jr. argued that, alongside cultivating the practical skills necessary for a successful and virtuous life, education should help students avoid having their minds "invaded by legions of half-truths, prejudices, and propaganda ... Education must enable one to sift and weigh evidence, to discern the true from the false, the real from the unreal, and the facts from the fiction." Ironically, however, and as this article explains, King's historic legacy now embodies the very issue he described. In the US and elsewhere, the systemic misrepresentation of his life and career only exacerbates the problematic treatment of the history of race. This article suggests some of the global repercussions of these distortions by examining how the civil rights movement and King are taught in the UK.

King's life - his social activism, ideas, leadership, and multiple legacies in the US and globally - are all now hotly contested and highly politicized topics within public education, as well as in wider public and political discourses. Indeed, this article contends that the routine oversimplification in classrooms of King's beliefs, tactics, and ultimate significance diminishes, rather than enhances, popular understandings of the entwined histories of race, white supremacy, and a variety of liberation struggles in the US and beyond. The same relentlessly celebratory, triumphalist tendency in depictions of King as a prophet of racial harmony and American civic perfectibility also undermines the global and contemporary relevance of his calls to radically restructure US social and economic life. At a time when scholarship on the African American freedom struggle is increasingly concerned with its international links and ramifications, this article examines how King, and the movement with which he is routinely presented as synonymous, are being

' Martin Luther King Jr., "The Purpose of Education," Jan.-Feb. 1947, in The Papers of Martin Luther King, Jr, Volume I, Called to Serve, January Ig29 to June I95I, ed. Clayborne Carson, Ralph Luker, and Penny A. Russell (Berkeley: University of California Press, 1993), 123-24. 
taught in British schools, as well as the consequences of that teaching for twenty-first-century understandings of Britain's own racial past, present, and possible futures. ${ }^{2}$

This article samples eight major textbooks and seven curricula specifications that cover King and/or the African American freedom struggle more generally, providing a clear sense of King's place in UK secondary schools and the political consequences of those representations for contemporary social-justice campaigns. ${ }^{3}$ Some of the textbooks consulted are broad survey texts of world history, while others are more targeted, as most UK exam boards offer specific courses on particular aspects of postwar America. Comparing our findings with those of similar studies conducted in the US, we argue that a more nuanced understanding of King can help UK teachers and students grapple with the ongoing issues of racism, poverty, and war that King identified when he visited the UK for the final time in November I 967 , just five months before his assassination. We also hope to underscore the global resonance and implications of the growing literature of the African American freedom struggle and its cultural memory. This is not simply an academic exercise given the highly charged contemporary significance of teaching global and racial history in a Britain still grappling with the long domestic aftermath of empire and colonialism; growing racial, ethnic, and religious

2 There is now an impressive literature on connections between the modern African American freedom struggle and global liberation movements, including several that focus on US-British and Irish relationships. See, for example, Anne-Marie Angelo, "The Black Panthers in London, 1967-1972: A Diasporic Struggle Navigates the Black Atlantic," Radical History Review, I03 (Jan. 2009), 17-35; Brian Dooley, Black and Green: The Fight for Civil Rights in Northern Ireland \& Black America (London: Pluto, 1998); Robin D. G. Kelley and Stephen Tuck, eds., The Other Special Relationship: Race, Rights, and Riots in Britain and the United States (New York: Palgrave Macmillan, 2015); Mike Sewell, "British Responses to Martin Luther King, Jr and the Civil Rights Movement, 1954-1968," in Brian Ward and Tony Badger, eds., The Making of Martin Luther King and the Civil Rights Movement (Basingstoke: Macmillan, 1996), 194-212; Joe Street, "Malcolm X, Smethwick and the Influence of the African American Freedom Struggle on British Race Relations," Journal of Black Studies, 38, 6 (July 2008), 932-50; Stephen Tuck, The Night Malcolm X Spoke at the Oxford Union: A Transatlantic Story of Antiracist Protest (Berkeley: University of California Press, 2014); Tuck, "The March on London: British-American Connections during the Civil Rights Movement," Bulletin of the German Historical Institute, Supplement II (2015), 81-97; Brian Ward, Martin Luther King in Newcastle: The African American Freedom Struggle and Race Relations in the North East of England (Newcastle upon Tyne: Tyne Bridge Publishing, 2017); Rob Waters, Thinking Black: Britain, 1964-1985 (Berkeley: University of California Press, 2019); Clive Webb, "Reluctant Partners: African Americans and the Origins of the Special Relationship," Journal of Transatlantic Studies, I4, 4 (Dec. 2016), 350-64.

3 Individual resources are cited as and when they are referred to in the text. A full list of textbooks and curricula consulted is provided at https://doi.org/10.1017/So02 1 875820000742 . 
diversity; and a resurgent white nationalism that fuelled support for Brexit and found expression in the Windrush generation scandal.4

Our survey of UK textbooks highlights many of the same issues that American scholars note about school coverage of the African American freedom struggle and US racial history. 5 The strongest alignment is in the emphasis on King himself, which undervalues the significance of grassroots activism, local leadership, and other important national civil rights figures. ${ }^{6}$ As one British textbook summarizes, "King's early life illustrates black problems and opportunities in mid-twentieth century USA. The story of his activism reads like a history of the civil rights movement. He was involved in most of its significant events."' Here King is not merely at the centre of the narrative, but becomes it. The entire history of the movement is traced through a

4 The Windrush generation refers to those who settled in the UK from British colonies in the Caribbean in the mid-twentieth century, the first of whom arrived on the MV Empire Windrush in 1948. Granted citizenship of the United Kingdom and Colonies by the 1948 British Nationality Act, many who arrived as children travelled on their parents' passports and never received their own documents. In $197 \mathrm{I}$ they were granted indefinite leave to stay, and so were never formally naturalized. In late November 2017 news reports began to surface of members of the Windrush generation losing their jobs, access to National Health Service care, and welfare benefits. Others were threatened with deportation or detained because they lacked official paperwork retrospectively deemed necessary under the Home Office's "hostile-environment" policies. Introduced by then Home Secretary Theresa May in 2012, the "hostile environment" was designed to curb immigration and deport huge numbers of non-British residents. See "Windrush Generation: Who Are They and Why Are They Facing Problems?”, $B B C$ News, i 8 April 2018, at www.bbc.co.uk/news/uk-4378224I, accessed 27 June 20r8; Amelia Hill, “'Hostile Environment': The Hardline Home Office Policy Tearing Families Apart," The Guardian, 28 Nov. 2017, at www.theguardian.com/uknews $/ 2017 / \mathrm{nov} / 28 /$ hostile-environment-the-hardline-home-office-policy-tearing-familiesapart, accessed 27 June 2018.

5 Assessing teaching standards in every US state in $20 \mathrm{I}$, the Southern Poverty Law Center (SPLC) concluded that "the [national] state of education about the civil rights movement is, in a word, dismal." Sixteen states did not require any instruction about the civil rights movement, and only three states-Alabama, Florida, and New York-received an A grade. See "Teaching the Movement: The State of Civil Rights Education in the United States," report by the Southern Poverty Law Center's Teaching Tolerance Programme, Montgomery, AL, Sept. 20 I I, 7. State history standards have often faced more general criticism, most notably in a 20 I I report from the Thomas B. Fordham Institute. See Sheldon M. Stern and Jeremy A. Stern, The State of State US History Standards 20II (Washington, DC: Thomas B. Fordham Institute, $20 \mathrm{II}$ ), at www.edexcellencemedia.net/publications/ 2011/20110216_SOSHS/ SOSS_History_FINAL.pdf, accessed 20 June 2018.

6 Derrick Alridge writes of a "messianic master narrative" that has emerged around King, as US textbooks "present prescribed, oversimplified, and uncontroversial narratives [that] obscure important elements in King's life and thought." Derrick Alridge, "The Limits of Master Narratives in History Textbooks: An Analysis of Representations of Martin Luther King, Jr.," Teachers College Record, ro8, 4 (April 2006), 662-86.

7 Vivienne Sanders, Civil Rights in the USA, 1945-1968 (London: Hodder Education, 2014), $82-83$. 
very selective rendering of his actions and ideas, which invariably ignores the more radical aspects of his social philosophy and overlooks the hundreds of thousands of other African Americans who articulated their own ideas of freedom and how it might be achieved. ${ }^{8}$

While both UK and US schools tend to ignore the transatlantic and global coordinates of the civil rights movement, that neglect has a particular social and cultural significance in the UK, conveniently consigning histories of racial prejudice and discrimination, along with the development of mass protests to combat them, to another place as well as another time. By celebrating King's stoic heroism and the initial legislative successes of the nonviolence with which he has become synonymous, Britain's imperial past is partially occluded; focus on the apparent singularity of US, especially southern, racial problems facilitates cultural amnesia regarding the historic and continuing significance of race and racism in the UK. Therefore our analysis of how King is misremembered in US and UK educational systems reveals remarkably similar themes, ideas, and assertions, but the implications of these distortions and oversimplifications are revealingly different.

Understandably, overstretched teachers on both sides of the Atlantic rely on textbooks, many of which have been critiqued by professional historians for their triumphalist representations of the past and failure to properly interrogate enduring problems of inequality. In Lies My Teacher Told Me, James Loewen argues that " $[\mathrm{t}]$ he stories that history textbooks tell are predictable; every problem has already been solved or is about to be solved." fectly into this hegemonic framework as a timeless prophet who forced the nation to acknowledge its original sin of slavery and correct its ugly racist legacies. While ideas of US perfectibility are less culturally ingrained in the UK, textbooks nevertheless propagate a similarly King-centric narrative, in which the 1955 bus boycott in Montgomery, Alabama marks "the real start of the US civil rights movement," and King's death in Memphis, Tennessee in

8 Though there is increasing evidence that UK schools are using King and other American civil rights heroes to mark Black History Month, British children are most likely to encounter King first in a formal classroom. By contrast, in the US, the annual King holiday - celebrated on the third Monday of January since 1986 - provides what John Wills calls "the stories, images and interpretive frames that give meaning to King and efforts to end segregation in US society," and exposes children to these topics before they formally study them. See John S. Wills, "'Some People Even Died': Martin Luther King, Jr., the Civil Rights Movement and the Politics of Remembrance in Elementary Classrooms," International Journal of Qualitative Studies in Education, I 8, I (2005), I 09-3 I, I I I-I 2.

9 James Loewen, Lies My Teacher Told Me: Everything Your American History Textbook Got Wrong (New York: Touchstone, 1996), I3. 
April 1968 serves as its conclusion. ${ }^{10}$ In this schema, Brown v. Board of Education (1954) is little more than a shadowy precursor to the "real" movement, and King is completely detached from earlier examples of black protest in all its varied forms. The black power era, too, becomes little more than a discrete, usually tragic, period of dangerous radicalism and militant excess, an ill-judged departure from the lofty, all-American ideals and nonviolent tactics of the early i960s southern campaigns associated with King. Especially important is the neglect of how generations of African American activists, from Ida B. Wells to W. E. B. Du Bois, and from King to Malcolm X and Stokely Carmichael, all understood how the realities of racial segregation, disenfranchisement, and wider forms of racial discrimination were bound up with the workings of American, indeed global, capitalism.

Coverage of King's own forays into the urban North, notably the SCLC's I 966 Chicago campaign, is variable. In Vivienne Sanders's Civil Rights in the USA, $1945-68$, the aims, tactics, and results of the Chicago movement are analysed over three and a half pages with some nuance and sophistication. Covering the Cicero riots, for example, Sanders affirms that systemic racialized inequalities and violence were national, not merely southern, problems. ${ }^{11}$ However, Paterson, Willoughby, and Willoughby's Civil Rights in the USA I865-I992 affords the entire Chicago campaign just I I 2 words, representing it as somewhat peripheral to the story of the modern freedom struggle, rather than illustrative of important national themes and critical in the development of King's own critique of American racism. ${ }^{\mathrm{I}}$

10 Sanders, 63, added emphasis. Most UK textbooks note that the Supreme Court's 1954 Brown decision had overturned the doctrine of "separate but equal" at the legal heart of Jim Crow society in the South. However, they often present this as more of a "sign of change," rather than an event that was itself the product of years of black courtroom protests and which had an inspirational effect on local black activism, not least emboldening Jo Ann Gibson Robinson and the Women's Political Council in Montgomery to step up pressure to desegregate the city's buses. Civil rights historians have long debated the periodization of the movement, but tend to make a much stronger case for Brown as the origin of the movement's "“classic' phase" than do most UK textbooks. See Steven F. Lawson, "Long Origins of the Short Civil Rights Movement," in Dannielle McGuire and John Dittmer, eds., Freedom Rights: New Perspectives on the Civil Rights Movement (Lexington: University Press of Kentucky, 20II), 9-37. Another catalytic event that receives little attention in UK textbooks is the murder of Emmett Till. Sanders, 61, includes the famous image of Till's bloated corpse, and notes that his murder "encouraged many blacks to become civil rights activists". Paterson, Willoughby, and Willoughby feature Till's murder in a small 93-word "Key Event" box, separate from the main text. See David Paterson, Doug Willoughby, and Susan Willoughby, Civil Rights in the USA I865-1992 (Harlow: Heinmann, 2009), 66.

${ }^{11}$ Sanders, 99-103.

12 Paterson, Willoughby, and Willoughby, 8I. It is worth noting that Paterson, Willoughby, and Willoughby's volume covers a much longer period of American history, and is divided into four sections: African American rights, labour rights, Native American 
Certainly, there is little appreciation in UK textbooks of how King applauded key tenets of black power, even as he rejected the slogan itself and refused to renounce nonviolent tactics and interracial cooperation. In textbooks on both sides of the Atlantic, King thus appears dehistoricized and depoliticized: a simple, moral advocate for nonviolence and racial tolerance, rather than a figure whose evolving ideas on wealth inequality and insistence on the intimate links between racism, imperialism, war, poverty, and capitalism demanded a radical overhaul of American life, politics, and socioeconomic structures. This misrepresentation impedes a fuller understanding of black power, underestimates its connections to other minority activism within the US, and neglects its global manifestations and influence. There is little recognition of the fact that, while their language and protest methods were often very different, King and many black power advocates shared similar understandings of how racial injustice was intertwined with powerful structural and ideological forces. Artificially setting King apart from earlier and later phases of the freedom struggle reduces his championing of racial pride, searing indictments of white supremacy, and denunciations of systemic inequalities to a more benign, cross-racial call for moral improvement and legal changes designed to make the existing socioeconomic system function more equitably; it thus avoids grappling with King's growing conviction that the system itself was fatally flawed and intrinsically racist. In this teaching model, it is unsurprising that King's seventeen-minute "I Have a Dream" speech attracts far more attention than his work on the Poor People's Campaign, which occupied the last eighteen months of his life.

British students are not required to learn about the US civil rights movement. Since it is not a mandatory part of any school curriculum, it is impossible to determine national norms and practices on the subject. Educational standards are also a devolved power, with Scotland and Northern Ireland developing curriculums separate to those in England and Wales. Scottish students undertake National examinations at age fifteen, and Highers at seventeen, with each examination accredited by the Scottish Qualifications Authority (SQA). Some Scottish schools and colleges also encourage students to undertake Advanced Highers at eighteen, but Highers are the main university qualifiers. Schools and colleges in England and Wales choose from four exam boards

rights, and women's rights. In their previous volume, Civil Rights and the USA, $1863-1980$ (Harlow: Heinemann, 200I), the authors gave two pages to discussion of Chicago. However, this coverage was still significantly underdeveloped. 
(OCR, Edexcel, WJEC, and AQA), each of which offers at least one history qualification at GCSE (national exams sat at age sixteen) and A level (sat at age eighteen), complete with its own teaching specifications, restrictions, and unit combinations. ${ }^{13}$ In Northern Ireland, GCSEs and A levels are awarded by the Council for the Curriculum, Examinations and Assessment (CCEA). ${ }^{14}$ There is no accepted body of knowledge that forms a prerequisite for studying history at university, and not all universities require A level history (or its equivalent) for entry into undergraduate history programmes. ${ }^{\text {s }}$ However, publishers do produce textbooks with specific exam boards in mind, with some working in official partnership with a particular board. ${ }^{16}$

Critics have lamented the "pernicious influence" of "shoddily written" textbooks, which "promise to enable teachers and students to produce the results," but which "crowd out other worthwhile textbooks for A level which stretch students more." ${ }_{17}$ Prior to the introduction of the National Curriculum and GCSEs in the 1980 s, British history teachers tended to express ambivalence towards textbooks. According to W. E. Marsden, more specific standardized assessment, which itself undergoes regular reform, has propelled the perceived "need" for textbooks to ensure that teachers and students are confident that their learning materials are sufficiently targeted towards exam

${ }^{13}$ In England and Wales, for example, "America, 1920-1973: Opportunity and Inequality," is an optional course for AQA GCSE History. In 2018 26,268 students were entered for this topic, which accounted for around $25 \%$ of a student's studies in GCSE History. In Scotland, "Free at Last? Civil Rights in the USA, I 9 I 8-1968," is one of ten options within category 3 "European and World Contexts" at National s (GCSE equivalent). If selected, this course would account for $29 \%$ of a student's grade in National 5 History.

${ }^{14}$ The current history specifications for Northern Ireland mention civil rights legislation in one optional A level module, entitled "The American Presidency, i 90 I-2000." If chosen, this module would account for $20 \%$ of a student's A level. There is no option to study US history beyond 1930 at GCSE level in Northern Ireland.

is This includes nine of the 24 Russell Group universities, a self-selecting body of "researchintensive universities." See Profile, June 2017, https://russellgroup.ac.uk/media/5524/ rg_text_june2017_updated.pdf, accessed 27 June 2019.

${ }^{16}$ Edexcel and Pearson Publishing are the same company, for example. See K.Crawford and S. Foster, "The Political Economy of History Textbook Publishing in England," in J. Nicholls, ed., School History Textbooks across Cultures (Oxford: Symposium Books, 2006), 93-104.

${ }^{17}$ Nicola Sheldon, "History Examinations from the I 960 s to the Present Day," Project Paper, Institute of Historical Research, 2, at www.history.ac.uk/history-in-education/projectpapers/topics.html, accessed I July 20 I9. Frequent syllabus changes have increased the pressure on authors and publishers to remain up to date. John D. Clare, a prolific textbook author, describes "writing at a frenetic pace" without copy editors. Quoted in Nicola Sheldon, "History Textbooks from 1965-2010," project paper, Institute for Historical Research, 201 I, 6, at www.history.ac.uk/history-in-education/project-papers/topics.html. 
success. ${ }^{18}$ As Nicola Sheldon writes, "students no longer do wider reading or read the works of leading academic historians (despite the fact that quotations from secondary works are often used in exams)."

Emphasis on attainment and exam results obviously affects teaching choices. Nevertheless, schools try to offer units that teachers feel confident with and want to teach, with an eye to materials that are already available, unless considerable sums of money exist to resource a new course. Consequently, teachers often speak of a "self-perpetuating" cycle of units: certain topics are taught year after year simply because the school already has relevant resources and teacher expertise. There is also a need to appeal to students, especially those beyond age thirteen, for whom historical study is usually optional. Religious studies, the other subject in which King occasionally appears, is compulsory until age eighteen in state-funded schools across England and Wales, and until age fourteen in Northern Ireland, although students across the UK can be withdrawn by their parents. ${ }^{20}$ In Scotland, schools are obliged to provide time for "Religious Observance," often referred to as "Time for Reflection" in nondenominational schools. ${ }^{21}$ Often only those schools with a religious affiliation require students to take formal exams in the subject. ${ }^{22}$

King's presence in compulsory religious education in the UK emphasizes his background within the black Baptist tradition and eventual occupation as a minister, focussing on his practical application of Christian teaching rather than on any formal contribution to theology. ${ }^{23}$ This befits the British tradition of teaching religion in terms of secular and ethical considerations rather than

${ }^{18}$ W. E. Marsden, The School Textbook: Geography, History and Social Studies (London: Woburn Press, 200I).

19 Sheldon, "History Textbooks from 1965-2010," 6.

20 "Section 375(3) of the Education Act 1996 requires the syllabus to reflect that the religious traditions of Great Britain are in the main Christian whilst taking account of the teaching and practices of the other principal religions represented in Great Britain." See Department for Children, Schools and Families, "Religious Education in English Schools: Non-statutory Guidance 2010," Iо, at https://assets.publishing.service.gov.uk/government/uploads/ system/uploads/attachment_data/file/I90260/DCSF-o0II4-20Io.pdf, accessed i9 June 2018. For Northern Ireland, see Department for Education, Statutory Curriculum, at www.education-ni.gov.uk/articles/statutory-curriculum, accessed I 2 Aug. 2018.

${ }^{21}$ Curriculum for Excellence: Religious Observance (Time for Reflection), 2014, at https:// education.gov.scot/improvement/documents/rme26-cfe-briefing-religious-observance.pdf.

${ }^{22}$ Recent research by the Religious Education Council of England and Wales shows that many schools are failing to provide religious education, despite a legal imperative to do so. See the 2017 report at www.religiouseducationcouncil.org.uk/news/religious-studies-gcse-entriesfall, accessed is June 2018.

${ }^{23}$ Luker has written that King was "perhaps the greatest American preacher of his era - but he was only very derivatively a theologian." Ralph Luker, "Plagiarism and Perspective: Questions about Martin Luther King, Jr.," International Social Science Review, 68, 4 (Fall 1993), 152-60, 154. See also Keith D. Miller, Voice of Deliverance: The Language of Martin Luther King, Jr., and Its Sources (Athens: University of Georgia Press, I992). 
strictly theological ones, and promoting interfaith understanding. ${ }^{24}$ " $[\mathrm{R}]$ outinely included among Christianity's most celebrated saints and sages," King was "the quintessential model of Christian activism in his time," according to Lewis Baldwin. Drawing on the resources of the church to advance his social-justice campaigns, King prioritized public service over ecclesiology. ${ }^{25}$ To this end, he often appears alongside Mahatma Gandhi, a crucial influence on King's understanding of nonviolent protest. While scholars continue to debate King's commitment to Gandhian ideas and the extent to which he absorbed them through intermediaries in the black church and his education, King's "openhearted reception of the theory and practice of nonviolent resistance from Gandhi" was nevertheless "an exemplary act of interreligious learning and receptivity," according to John Thatamanil. ${ }^{26}$ Textbooks that present King alongside Gandhi therefore stress how core ethical and moral values can transcend religions, as well as alerting students to the concepts of anticolonial struggle and solidarity. However, they also raise questions about how the British educational system dehistoricizes world figures (especially those of colour) and what it means to hold a nonChristian figure like Gandhi in such reverence while prioritizing Christian experiences. $^{27}$

${ }^{24}$ Scholars have attributed this to the influence of Ninian Smart, whose work in the late 1960 s and the I970s encouraged a non-confessional religious education in schools, "chiefly to advance an understanding of religion and to promote religious tolerance." See L. Philip Barnes, "The Contribution of Professor Ninian Smart to Religious Education," Religion, 31, 4 (Oct. 200I), 317-19.

${ }^{25}$ Lewis Baldwin, The Voice of Conscience: The Church in the Mind of Martin Luther King, Jr. (New York: Oxford University Press, 2010), 4.

${ }^{26}$ John Thatamanil, "The Hospitality of Receiving: Mahatma Gandhi, Martin Luther King, Jr., and Interreligious Learning," in Lewis V. Baldwin and Paul R. Dekar, eds., "In an Inescapable Network of Mutuality": Martin Luther King, Jr. and the Globalization of and Ethical Ideal (Eugene, OR: Cascade Books, 2013), I3 I-51, 132-33. Hodder argues that the attempt to cast King as "America's Black Gandhi" was both strategic and short-lived. "The translation of Gandhi into American culture was a selective process which sectioned off the readily transferable message of nonviolence and civil disobedience from what was perceived as Gandhi's more exotic and culturally contingent eccentricities." See Jake Hodder, "Casting a Black Gandhi: Martin Luther King Jr., American Pacifists and the Global Dynamics of Race," Journal of American Studies, First View, 3, published online I 4 May 2019, at https://doi.org/10.1017/So021875819000033, accessed 27 May 2020. See also Miller.

${ }^{27}$ According to Thatamanil, I 34, King "had neither the time nor the inclination to attend to the Indic elements of Gandhi's thought." Miller, 98. King nevertheless faced accusations from white Southern Baptist leaders that he was "rejecting the cardinal tenets of biblical Christianity for the heathen philosophy of Mahatma Gandhi." See Bill J. Leonard, "A Theology for Racism: Southern Fundamentalists and the Civil Rights Movement," Baptist History and Heritage, 34, I (Winter 1999), 49-68, 63. 
In Directions, a religious-education textbook for eleven- to fourteen-yearolds, a chapter on Christians and justice profiles both King and Gandhi alongside Desmond Tutu, Mother Teresa, and the Dalai Lama, despite the fact that Gandhi and the Dalai Lama are not Christian figures. In such depictions, King is simply a peaceful leader, using marches to draw attention to the mistreatment of African Americans. He sits alongside Gandhi and other exalted moral leaders, disconnected from his own life story and the realities of the civil rights movement. In Directions, King "led a peaceful campaign of civil disobedience," after "a black woman, who had paid for her ticket on the bus, was told to give up her seat to a white man." 28 That even Rosa Parks remains unnamed in this summary exemplifies not only a wider pattern of neglecting or marginalizing the role of women in histories of the movement, but also the routine presentation of King as a unique, almost superhuman, moral exemplar. In this context, the mythologized King, Gandhi, and their decontextualized moral counterparts serve as little more than what sociologist Steven Hitlin calls "Bright Lights, signposts of what a culturally defined moral person might be like." ${ }_{29}$ It would appear that Newt Gingrich was right: King "transcends all of us." 30

Similar oversimplifications of King in UK history classrooms derive from a more complicated backstory. Here, the teaching of the civil rights movement, and of African American history in general, must be viewed in light of twentyfirst-century political upheavals surrounding the UK's history curricula, and damning findings regarding the lack of diversity in the history profession. It is a component of a complex dynamic that encompasses recognition of what subjects are popular with students and teachers, the need for meaningful diversity within history teaching, and highly politicized discussions surrounding British identity in an era of burgeoning nationalism, xenophobia, and racial chauvinism. In the year 2000, only one in six units of A level study in England had to be devoted to British history. By 2008, this had expanded to one in four, reflecting a political concern to develop a greater, very particular sense of national identity. ${ }^{31}$ In 2010 , Conservative Education Secretary Michael Gove announced his explicit desire to privilege Britain's "island story," championing a parochial history that squandered the opportunity to

${ }^{28}$ Ina Taylor, Directions, Volume I (Cheltenham: Nelson Thornes, 2002), 43.

29 Steven Hitlin, Moral Selves, Evil Selves: The Social Psychology of Conscience (New York: Palgrave Macmillan, 2008), i 38.

${ }^{\circ}$ Quoted in Robin Toner, "Saving a Dissenter from His Legend," New York Times, 20 Jan. I986, A24.

${ }^{31}$ Richard J. Evans, "The Wonderfulness of Us (The Tory Interpretation of History)," London Review of Books, 33, 6 (I7 March 20II), at www.lrb.co.uk/v33/no6/richard-jevans/the-wonderfulness-of-us, accessed 5 Jan. 20 I 8. 
teach schoolchildren about Britain's changing place in and relationships with the rest of the world in favour of a jingoistic fetishization of key dates, heroes, and events from a triumphalist version of Britain's past. In 2013, Richard J. Evans, Regius Professor of History at the University of Cambridge, complained that the extent to which Gove's revised history curriculum focussed "exclusively on British history" was "comical." ${ }_{2}$

However, while Gove's changes to the National Curriculum only applied to compulsory pre-GCSE teaching (i.e. pre-fourteen) in England, many teachers and academics suspected that his sights were also set on post-fourteen teaching. ${ }^{33}$ After all, as Evans wrote at the time, there is a noticeable "change of direction" for young people who elect to carry on beyond the mandatory history provision to study history at GCSE and/or A level. At that point, Evans observes, "Out goes British history, out goes the long sweep of the centuries, out go social, economic and cultural history. Students take Modern World History, which is emphatically focussed on politics and international relations [and] 'education for citizenship', as the exam boards put it." 34 Units in American history prove popular within this model, with civil rights, the Great Depression, and Vietnam widely taught at GCSE level. A 2014 report by the exam group Cambridge Assessment cited "Civil Rights in the USA (I865-1992)" as the second-most-popular module chosen for the affiliated OCR A level, after "The Russian Dictatorship (1855-1992)." Third on the list was "Dictatorship and Democracy in Germany (1933-1963)," before the first British entry, "The Mid-Tudor Crises (1536-1569)" appeared in fourth place. ${ }^{35}$

While OCR is currently the smallest of the three providers of A level history qualifications in England, the backlash to its 2014 survey was indicative of a wider pattern. ${ }^{36}$ In 2010, conservative historian Niall Ferguson praised

32 Richard J. Evans, "Michael Gove's History Curriculum Is a Pub Quiz Not an Education," New Statesman, 2 I March 2013, at www.newstatesman.com/culture/culture/2013/03/ michael-gove\% $2 \% 80 \% 99$ s-history-curriculum-pub-quiz-not-education, accessed is June 2018.

${ }_{33}$ Devolved powers ensured that Gove's reforms applied only to England, despite the fact that Gove is himself Scottish, educated in Aberdeen.

${ }^{34}$ Evans, "The Wonderfulness of Us."

35 Cambridge Assessment, "Top ro Topics Studied by A Level History Students," I 3 Aug. 2014, at www.cambridgeassessment.org.uk/news/top- Io-topics-studied-by-a-level-historystudents, accessed 22 Nov. 2018.

${ }^{36}$ History was the fifth-most-popular A level subject in 2017, when according to the Joint Council for Qualifications, 50,3 I I students took A level examinations in history. See www.jcq.org.uk/examination-results/a-levels/2017/main-results-tables, accessed 9 Jan. 2018. For OCR's recent market share see Annual Qualifications Market Report 2017I 8, I2, at https://assets.publishing.service.gov.uk/government/uploads/system/uploads/ attachment_data/file/778824/AQMR_-_academic_year_20I7_to_2018.pdf, accessed I 
Gove's desire to overhaul the curriculum, lamenting that approximately 80 percent of A level students studied Nazi Germany (an out-of-date figure that has circulated since 2006), and that "all three" of his children "had heard of the Reverend Martin Luther King, but none could tell me anything about Martin Luther." 37 Tom Utley offered a similar parental anecdote as part of a Daily Mail attack on Labour Party leader Jeremy Corbyn, who marked British Black History Month in 2018 by lamenting the scarcity of black history in British schools. "I thought it odd, and still do, that at the age of I I our son had been instructed to study [King], before he'd learned the basics of the story of our past," Utley wrote, recalling the time that his son misunderstood teacher instructions, and wrote an essay on Martin Luther, rather than Martin Luther King. "Like so much else he was taught, this choice of subject matter [Martin Luther King rather than Martin Luther] struck me as nakedly political in intent," Utley reflected, "more concerned with indoctrination than education." ${ }_{38}$ Notwithstanding the profound influence on Gove's "island story" that Ferguson and Utley paradoxically ascribed to a German theologian, their complaints reflect right-wing dissatisfaction with the perceived levels of both world and modern history in UK schools, a popular battlefield in culture wars rooted in differing interpretations of Britain's imperial past, the historical construction of race, and the continued impact of historic, often transnational, regimes of racial oppression. Indeed, Ferguson himself was eventually sidelined by Gove, after his ideas regarding Britain's place in a broader Western ascendancy proved too global for Gove's attempts to "put British history at the heart of a revived national

July 2019. Cannadine, Keating, and Sheldon argue that UK exam boards are famously "secretive and unaccountable." See David Cannadine, Jenny Keating, and Nicola Sheldon, The Right Kind of History: Teaching the Past in Twentieth-Century England (Basingstoke: Palgrave Macmillan, 20 I I), 234.

37 Niall Ferguson, quoted in Anushka Asthana and Amardeep Sohi, "Niall Ferguson: 'Rid our schools of junk history'," The Guardian, 2 I March 2010 , at www.theguardian.com/education $/ 2010 / \mathrm{mar} / 2 \mathrm{I} /$ niall-ferguson-history-schools-gcse, accessed $8 \mathrm{Jan}$. 2018. According to data from AQA, the most popular exam board for A level history, "The Tudors: England, I485-1603" was the most popular A level entry in 2018. The next-mostpopular module, "Tsarist and Communist Russia, i $855-1964$," was sat by fewer than half the numbers that selected Tudor history. "Democracy and Nazism: Germany, i 9 i 8 1945" was AQA's fourth-most-popular topic, with "The Making of Modern Britain, 195 I-2007" third. AQA, Topic Entry Data, 2018.

${ }_{38}$ Tom Utley, "If Corbyn Wants to Teach Our Children History, I Suggest He Starts with the Masses killed by Marxism," Daily Mail, i I Oct. 2018, at www.dailymail.co.uk/debate/ article-6267035/TOM-UTLEY-Corbyn-wants-teach-children-history-suggest-starts-

Marxism.html, accessed 2i Oct. 2018. 
curriculum" - a curriculum that embodied a resolutely white version of that history. ${ }^{39}$

Like the efforts to expand black studies in Britain's universities, calls for more black history in UK schools are often dismissed by those who seek to protect the privileged place of white, Eurocentric history. Noting this often "subliminal effort to hold on to the right to interpret the Black British experience and to assert what is best for Black British people," Mark Christian references criticisms of black studies penned in the 1970 s and 1980 s, in which leading white academics Ernest Cashmore and Barry Troyna asserted that the positive image of "the black man" in "Black or Afro-studies ... has no necessary connection with life in England in the late twentieth-centurynot even for blacks." 40 The idea that African history could be considered "meaningless to contemporary Black youth, yet ancient Roman history is not questioned as being futile to the lives of working-class White youth," is at the heart of British education, Christian argues, and "has proved to be a major obstacle to the development of a coherent and stable Black Studies curriculum in the British education system." Emphasizing further structural problems, Christian notes that "[v]ery few scholars have emerged from the British education system to teach Black Studies in the fullest sense." ${ }^{41}$ As a 20 I 8 Royal Historical Society (RHS) survey revealed, black and ethnic-minority students largely rejected history as an area of study. While 85 percent of all academics in Britain are white, for historians the figure rose to 93.7 percent. Black historians made up just 0.5 percent of history departments in the UK. ${ }^{42}$

\section{III}

For those invested in the value of non-white British experiences and the idea that studying and teaching history beyond Gove's carefully solipsized island is a fruitful and rewarding endeavour, King offers interesting avenues for

39 Michael Gove, "All Pupils Will Learn Our Island Story," speech to the Conservative Party Conference, 5 Oct. 20I0, at https://conservative-speeches.sayit.mysociety.org/speech/ 60I44I, accessed i9 June 2018.

40 Mark Christian, "Black Studies in the UK and US: A Comparative Analysis," in Jeanette R. Davidson, ed., African American Studies (Edinburgh: Edinburgh University Press, 20 Io), I 49-67, I 56; Ernest Cashmore and Barry Troyna, "Black Youth in Crisis," in Cashmore and Troyna, eds., Black Youth in Crisis (London: George Allen \& Unwin, 1982), I 5-34, 24.

${ }^{41}$ Christian, I 5 5. Birmingham City University launched the UK's first black studies degree in 20 I 7. The UK's first postgraduate course in black studies opened at Goldsmiths, University of London in September 2019.

${ }^{42}$ Royal Historical Society, "Race, Ethnicity \& Equality in UK History: A Report and Resource for Change," Oct. 20I8, at https://5hmih4aktue2uejbsihsqt3 I-wpengine. netdna-ssl.com/wp-content/uploads/20 I 8/Io/RHS_race_report_EMBARGO_ooo I_

I8Oct.pdf, accessed I9 Nov. 20 I 8. 
exploration. ${ }^{43}$ But if US textbooks routinely confine the African American struggle to what Jacquelyn Dowd Hall calls "a single halcyon decade" and "limited noneconomic objectives," there is a tendency to compartmentalize it still further in the UK, by teaching the civil rights movement only in its American manifestation and ignoring the links and networks that encouraged and facilitated transatlantic protest movements and solidarity. ${ }^{44}$ Although individual teachers may well make their own links between local, national, and international history, our study of UK textbooks and curricula shows that they are not being formally supported or encouraged to do so.

By neglecting British links to the long African American freedom struggle, including British involvement in the Atlantic slave trade which made that struggle necessary, UK curricula and textbooks limit teachers and students to a grand historical narrative that often feels extremely distant - both geographically and culturally. This prevents students from making connections between global histories and those of their own communities. King's 1967 visit to Newcastle upon Tyne, for example, is not just "a fascinating piece of local history," as Brian Ward notes, but a reminder of how individual stories contribute to and connect with "far bigger historical and geographical worlds." 45

King's decision to accept an invitation to Newcastle, a city he had probably never heard of, reveals much about his "evolving sense of international leadership and responsibility, but also about how expressions of approval and encouragement from overseas strengthened his resolve to continue the struggle in the US, especially at times of acute political and personal crisis." 46 A vocal critic of America's continued military involvement in Vietnam, King was keen to stress the global intersections of racism, imperialism, and capitalism when he visited the UK in 1967. Exasperated by US foreign and domestic policy, King's vexed but often productive relationship with President Lyndon Johnson had deteriorated. He was also subject to increasing scrutiny and harassment from the FBI, which had wiretapped his phones since 1963. Moreover, King's increased emphasis on the economic and social inequalities endemic to capitalism and strident calls for federal intervention in addressing those problems alienated many who had supported black demands for basic civil and voting rights. Erstwhile civil rights allies, such as Roy Wilkins of the NAACP and Whitney Young of the National Urban League, began to

${ }^{43}$ Evans, "The Wonderfulness of Us."

${ }^{44}$ Jacquelyn Dowd Hall, "The Long Civil Rights Movement and the Political Uses of the Past," Journal of American History, 91, 4 (March 2005), I 233-63, I 234.

45 Ward, Martin Luther King in Newcastle, 17. For more on King as a global figure see Jason Sokol, The Heavens Might Crack: The Death and Legacy of Martin Luther King, Jr. (New York: Basic Books, 2018). 
question King's patriotism and lambasted him for distracting attention from the black freedom struggle and risking white support. Black power leaders questioned the wisdom of King's tireless pursuit of interracial alliances, while some, including the Black Panther Party, doubted the effectiveness of King's nonviolent philosophy in the face of continued racial brutality, embraced armed self-defence tactics, and offered alternative means of protest. King's Newcastle visit, and British responses to it amid heated domestic debates over immigration policy and proposed legislation to protect minority rights, reflected all of these themes: thus it offers the potential to scrutinize key issues in King's final years, and to do so in relation to crucial developments in Britain's racial history, not least the simultaneous escalation of minority and white supremacist activism. ${ }^{47}$

As is the case in the US, however, few UK textbooks cover this later period of King's life, other than to briefly reference urban rebellions that "began" in Watts, Los Angeles, just days after Lyndon Johnson signed the 1965 Voting Rights Act, and spread across American cities in subsequent summers. Such unrest, usually attributed to the national rise of black power, rather than community responses to specific, local events, often works to cast King as the "moderate" voice - simultaneously downplaying his radicalism and relegating black power to a reactionary and damaging deterioration of the "true" movement. In her A level textbook Civil Rights in the USA, 1945-68, Vivienne Sanders poses the following "key question:" "What was the impact of Watts upon Martin Luther King?" but provides no details of the events that precipitated the rebellion, the scale of the damage, or even the loss of thirtyfour lives until much later in the book, when the uprising is briefly reassessed as part of both "The Rise of Black Power in the 1960s" and "The factors that stopped Johnson doing more for blacks." ${ }^{48}$ As such, there is a problematic compartmentalization of civil rights issues - chapters on King as the mainstream movement, followed by the black power declension narrative, and a final assessment of presidential approaches. Thus, while Sanders notes

47 For King's new public radicalism and increasingly isolated and embattled position see Adam Fairclough, To Redeem the Soul of America: The Southern Christian Leadership Conference and Martin Luther King, Jr. (Athens: University of Georgia Press, 1987), 309-3 I, 333-45, 352-53; Thomas Jackson, From Human Rights to Civil Rights: Martin Luther King, Jr. and the Struggle for Economic Justice (Philadelphia: University of Pennsylvania Press, 2007); Sylvie Laurent, King and the Other America: The Poor People's Campaign and the Quest for Economic Equality (Berkeley: University of California Press, 2018). For the split with Johnson see Sylvia Ellis, Freedom's Pragmatist: Lyndon Johnson and Civil Rights (Gainesville: University Press of Florida, 2013), 235-38, 254-56. For the FBI campaigns against King see Kenneth O'Reilly, Racial Matters: The FBI's Secret File on Black America (New York: Free Press, 1989), I 2 I-55, 242-45, 286-91.

${ }^{48}$ Sanders, Civil Rights, 99, added emphasis, I 20, $149-50$. 
King's assessment of the riots as "a class revolt," Watts serves only as a turning point in the dominant textbook narrative, in order to make sense of King's later disappointments in Chicago and explain the rise of "extremists" such as Stokely Carmichael.49 "[S]erious rioting in Los Angeles gave a violently unpleasant foretaste of things to come," Paterson, Willoughby, and Willoughby write. "The civil rights movement had suddenly entered another phase." 50

Consistently presented as the heroic early movement's more militant, more violent, less temperate descendent, "Black Power is often reduced," historian Peniel Joseph writes, "to symbols associated with its advocacy of self-defense (i.e., the Black Panthers)." The prominence of this narrative in public memory and popular culture, Joseph argues, "creates a situation in which the BPM [black power movement] can be conveniently blamed for the demise of the Civil Rights Movement, rather than being viewed as an alternative to the ineffectiveness of civil rights demands in critical areas of American life." ${ }_{5}$ Recuperating the histories of civil rights activity outside the South, as well as what Joseph calls "the multilayered roots of Black Power-era radicalism," scholarly work by Timothy Tyson and Jeanne Theoharis, amongst others, complicates this crude dichotomy..$^{52}$ Yet such binaries endure in textbooks, and are reinforced by Hollywood films such as The Butler (Lee Daniels, 2013), which implies that black power attracted an angry, radical, and uncouth section of black society that was opposed to the further development of an interracial America and disrespectful of its elders. ${ }^{53}$

49 Ibid., 99.

so Paterson, Willoughby, and Willoughby, Civil Rights, 77. The authors never reveal that 34 people were killed in Watts, just that "I 4,000 troops were required to restore order and 4,000 people were arrested."

${ }^{51}$ Peniel E. Joseph, "Toward a Historiography of the Black Power Movement," in Joseph, ed., The Black Power Movement: Rethinking the Civil Rights-Black Power Era (New York: Routledge, 2006), I-25, 3. Murch illustrates that many key Black Panthers actually repudiated the label Black Power, "and chose instead to emphasize the international, and ultimately 'intercommunal' nature of their organizing." Donna Murch, "When the Panther Travels: Race and the Southern Diaspora in the History of the BPP, 1964-1972," in Nico Slate, ed., Black Power Beyond Borders: The Global Dimensions of the Black Power Movement (New York: Palgrave Macmillan, 2012), 57-78, 59.

52 Joseph, 4. See Timothy B. Tyson, Radio Free Dixie: Robert F. Williams and the Roots of Black Power (Chapel Hill: University of North Carolina Press, 200I); Jeanne Theoharis, "Hidden in Plain Sight: The Civil Rights Movement outside the South," in Mathew Lassiter and Joseph Crespino, eds., The Myth of Southern Exceptionalism (New York: Oxford University Press, 2009), 49-73.

53 The Butler presents black power as a negative force, dividing black America after a time of great unity. See Eddie Glaude, "Princeton Professor Analyzes 'Lee Daniels' The Butler.' Radio Interview with Dean Richards," WGN Chicago, 20 Aug. 2013, http://wgnradio. com/2013/08/20/princeton-professor-analyzes-lee-daniels-the-butler. The Butler 
By the end of Sanders's chapter on King, she notes, "Within the southern context, King was a political radical who sought the vote for the disfranchised and a social radical who sought racial equality." 54 Such qualifiers are rare in a textbook committed, perhaps inevitably, to weighing King's contribution to the movement in the reductive "pros-and-cons" style of an A level exam essay. There is no place here for the fact that, as early as 195 I, King had written how "American capitalism has seen its best days," no recognition of his commitment to confronting economic inequalities even during the early phase of his activism. ${ }^{5}$ Likewise, the textbook devotes only a paragraph to King's criticisms of the Vietnam War (a conflict erroneously defined as beginning in 1965) and offers no real insight into the range of responses his antiwar stance generated. ${ }^{56}$

It is not uncommon for the later chapters of King's life to be largely omitted from textbook narratives, as his demands for a drastic overhaul of American society and values raise difficult questions of both the past and the present. King had been radicalized by the movement itself, and by its bitter disappointments when faced with the limitations of white liberalism. As Julian Bond noted, King's

last years were marked by changes in black America's demands and white America's response. In 1955 in Montgomery, blacks had peacefully asked for seats at an abundant table; they could gain, and no one would lose. As the movement eliminated legal segregation and attacked segregation's legacy, demanding relief from the residual damage it continued to do, many whites began to believe blacks wanted the entire table for themselves. ${ }^{7}$

Such insight is far removed from the focus on a short but effective period of peaceful change currently propagated by school textbooks: a valorizing narrative, in which King led the US closer towards the nation it was destined to become. Indeed, since the moment of his assassination in April 1968, when Thomas Jackson argues white Americans set aside "their recent fear of King as a radical incendiary," the slain activist was frozen "as a moderate "civil rights' leader appealing to the nation's highest ideals." ${ }^{8}$ King's "I Have a

personifies this ideological divide through its protagonist Cecil Gaines (Forrest Whitaker), who struggles with and temporarily disowns his son Louis (David Oyelowo) during the latter's transition from peaceful nonviolent activist to black power advocate. See Megan Hunt, "Southern by the Grace of God': Religion and Race in Hollywood's South since the 1960s," PhD diss., Northumbria University, 2016, 186-7, at http://nrl.northumbria. ac.uk/32576/I/hunt.megan_phd.pdf.

${ }^{54}$ Sanders, io5.

5s Martin Luther King, "Notes on American Capitalism," n.d. (195 I), in The Papers of Martin Luther King, 435-36.

${ }^{56}$ Sanders, 132, 84.

57 Julian Bond, "Remember the Man and the Hero, Not Just Half the Dream," Seattle Times, 3 April 1993, available at http://old.seattletimes.com/special/mlk/perspectives/reflections/ bond.html, accessed 4 Jan. 2018.

58 Jackson, From Human Rights to Civil Rights, 359. 
Dream" speech, delivered from the Lincoln Memorial during the March on Washington for Jobs and Freedom in August 1963, became the central image and soundtrack of this vision of King. It was "King at his best," according to Sanders, because "the morality [of the March] could not be doubted." 59 It is never mentioned that the March, co-organized by eminent labour leader A. Philip Randolph and socialist intellectual Bayard Rustin, was for "Jobs and Freedom," reflecting a clear understanding that economic opportunity and racial equality were intimately connected. Textbooks also dedicate little, if any, attention to the frustrated militancy evident in the early sections of King's speech, when he implicitly indicted the Kennedy administration's failure to act forthrightly on civil rights and explicitly condemned a socioeconomic system in which "the Negro lives on a lonely island of poverty in the midst of a vast ocean of material prosperity." 60

Regularly presented as a powerless bystander to the turbulence of the late I 960 , King usually serves as a welcome reminder of what historian-activist Van Gosse calls the "'good' sixties," before his "dream" turned nightmare in the wake of black power, rioting, and the travesty of Vietnam. ${ }^{61}$ In Montgomery, as in many campaigns during the late 1950 s and early i960s, King's image of respectability was consciously crafted. ${ }^{62}$ But endorsing respectability was not merely an expedient performance; it helped shape and construct an image of the movement that cemented itself in public consciousness. As such, it contributed to the rejection and fear of other forms of black political organization, especially those that were not rooted in the church and/or nonviolence, or which posited radical solutions to deep systemic inequalities. Nowhere is this more evident than in the representation of Malcolm X, whose major role in the development of African American political thought and protest usually serves only to highlight King's putative moderation and render the latter more palatable as the embodiment of shared national values. In school textbooks, the two men and their ideas are regularly stripped of complexity, their common ground eroded, their respective efforts to build

59 None of the textbooks assessed for this article afford the March on Washington its full title - the March on Washington for Jobs and Freedom.

${ }^{60}$ Martin Luther King, "I Have a Dream," 28 Aug. 1963, in James M. Washington, ed., I Have a Dream: Writings and Speeches that Changed the World (San Francisco: HarperSanFrancisco, 1992), 102-6.

${ }^{61}$ Van Gosse, "Consensus and Contradiction in Textbook Treatment of the i $960 s, " J o u r n a l$ of American History, 82, 2 (Sept. 1995), 658-69.

${ }^{62}$ Marisa Chappell, Jenny Hutchinson, and Brian Ward, "'Dress Modestly, Neatly ... as if You Were Going to Church': Respectability, Class and Gender in the Montgomery Bus Boycott and the Early Civil Rights Movement," in Peter J. Ling and Sharon Monteith, eds., Gender and the Civil Rights Movement (New Brunswick, NJ: Rutgers University Press, 2004), 69-100, 70-72. 
international bonds forgotten, so that they can be conveniently presented as polar opposites.

In a manner that reflects the overly prescriptive nature of standardized assessments and mark schemes, UK students are frequently required to compare King and Malcolm X, to list differences between them, emphasizing King's middle-class southern and Christian background in contrast to Malcolm X's urban, working-class credentials and cachet among African Americans living in the "North" - an elastic term that is often a synonym for "cities" and usually encompasses anywhere not in the South, thereby flattening distinctions between, for example, the North East, the Mid-west and the West Coast. ${ }^{63}$ "Martin Luther King and his civil rights successes in the South seemed irrelevant to blacks living in the poor areas of American cities," John Clare writes in GCSE textbook Modern World History, "where poverty, deprivation and unemployment were rife." ${ }^{4}$ While Malcolm X did, of course, offer alternative visions of and pathways to African American liberation, and was undoubtedly more rooted in the urban North than was King, statements such as this falsely imply not only that the black South was entirely under King's influence, but also that it was largely middle-class. It also obscures the widespread rebellions that erupted in northern cities in the wake of King's assassination and which were, in part at least, reflections of his importance in those communities.

Such factual lacunae and interpretive flaws have a lasting impact on how students dichotomize the civil rights movement between the South and the North, a geographical error that also encourages the tendency to exaggerate the discontinuities between ostensibly civil rights struggles (associated with the South before 1965) and black power protests (associated with the post1965 North). ${ }^{65}$ In these constructions, King and Malcolm X form the basis for deceptively simple, value-laden comparisons, contributing to ideas of a misguided "descent" into black power. Malcolm's embrace of Islam, the evolution of his religious beliefs, and their impact on his political ideology and activism

${ }^{63}$ Murch, "When the Panther Travels," 60, argues that the internal migration of millions of Americans between 1940 and 1970 necessitates a diasporic approach to northern civil rights and black radicalism.

${ }^{64}$ John Clare, AQA B: Modern World History (Oxford: Pearson/Heinemann, 2009), 229.

65 Works that challenge these dichotomies include Brian Purnell and Jeanne Theoharis, eds., with Komozi Woodard, The Strange Careers of the Jim Crow North: Segregation and Struggle Outside the South (New York: New York University Press, 2019); Thomas Sugrue, Sweet Land of Liberty: The Forgotten Struggle for Civil Rights in the North (New York: Random House, 2009); Matthew D. Lassiter and Joseph Crespino, eds., The Myth of Southern Exceptionalism (New York: Oxford University Press, 2010); Jeanne Theoharis and Komosi Woodard, eds., Freedom North: Black Freedom Struggles outside the South, 1940-1980 (New York: Palgrave Macmillan, 2003). 
are rarely given much attention in this framework. Nor is the fact that his assassination in 1965 prevented his engagement with the formal adoption of black power that Stokely Carmichael first popularized in 1966. Malcolm's influence on Carmichael and other black power radicals is undisputed. But the frequency with which students assume that Malcolm X was physically present for this "new" wave of protest reveals their repeated exposure to a factually problematic as well as intellectually unsophisticated timeline. The refusal to view King and Malcolm as individuals whose ideas and activism evolved and occasionally overlapped obscures their shared understanding of an international system of white supremacy historically rooted in colonialism and empire, and sustained by the workings of global capitalism. Like their American counterparts, British textbook authors have found little room to explore this common intellectual and often transnational ground. Moreover, they are also largely reluctant to engage with what Gosse provocatively describes as "one of the hardest facts about the sixties: when it came to nonwhite activists, national, state, and local government agencies engaged in systematic oppression." 66

\section{IV}

Considerable work has been undertaken by historians, educational specialists, and sociologists to document King's legacy in the US, while geographers have discussed his memory as embodied in the particular (street names and municipal buildings) and the global (his vision of an interconnected Beloved Community). ${ }^{67}$ Similarly, much has been written about what Thomas Jackson calls "the plasticity of the King icon," which enabled President Ronald Reagan "to turn King into a color-blind opponent of racial 'quotas'

66 Gosse, 663.

67 See Aldridge, "The Limits of Master Narratives"; Wills, "Some People Even Died"; Lewis V. Baldwin and Rufus Burrow Jr, eds., The Domestication of Martin Luther King Jr.: Clarence B. Jones, Right-Wing Conservatism and the Manipulation of the King Legacy (Eugene, OR: Cascade Books, 2013); Derek H. Alderman, "School Names as Cultural Arenas: The Naming of US Public Schools after Martin Luther King, Jr.," Urban Geography, 7, 2 (2013), 601-26; Alderman, "Street Names and the Scaling of Memory: The Politics of Commemorating Martin Luther King, Jr within the African American Community,' Area, 35, 2 (June 2003), I63-73; Joshua F. J. Inwood, "Searching for the Promised Land: Examining Dr Martin Luther King's Concept of the Beloved Community," Antipode, 4I, 3 (2009), 487-508; Lewis V. Baldwin and Paul R. Dekar, eds., "In an Inescapable Network of Mutuality:" Martin Luther King, Jr. and the Globalization of an Ethical Idea (Eugene, OR: Cascade Books, 2013). 
and affirmative action." ${ }^{68}$ The civil religion that has absorbed King has long been used "as a tool of social cohesion and political legitimation," Jana Weiss writes. ${ }^{69}$ Yet, as Ward observes, "despite a flourishing literature on race and the construction of social memory in the US, [scholars] have paid relatively little attention to international efforts to commemorate the African American freedom struggle," or to the ways in which its legacy circulates beyond America. ${ }^{70}$

The scramble to define King's "meaning" and legacy have the most acute political consequences in the US, where civic pride and national identity are often rooted in ideas of the country as an ever-improving, ultimately perfectible nation, ideas frequently challenged by the manifest persistence of racial inequalities and injustice. King "was a man who wrested justice from the heart of a great country," Reagan observed on the first King Day public holiday in 1986, "And he succeeded because that great country had a heart to be seized." ${ }^{1}$ But King's legacy and enduring global celebrity have consequences for contemporary discussions of race all over the world. In Why I'm No Longer Talking to White People about Race, Reni Eddo-Lodge's best-selling 2017 treatise on the overt and subtle manifestations of white supremacy in modern Britain, the author explicitly refers to King on four occasions. She draws attention to concurrent but largely forgotten events in the UK that echoed King's rhetoric and tactics, such as the 1963 Bristol Bus Boycott, and recalls the "American-centric educational displays and lesson plans" she encountered in school-her only formal introduction to black history before university. Most tellingly, Eddo-Lodge, a black British woman, discusses the correspondence she received from white people, who used King's words "in attempts to prove to me that my work is misguided, that I am doing it wrong." Recounting King's speech at the 1963 March on Washington for Jobs and Freedom, Eddo-Lodge's British critics informed her that "Martin Luther King, Jr. wanted a world in which people were not judged on the colour of their skin, but on the content of their character." Discussing the white backlash to ideas of "safe spaces" for people of colour to discuss problems and strategies for change, Eddo-Lodge suggests that

${ }^{68}$ Jackson, From Civil Rights to Human Rights, 360-61. See also, Ronald Turner, "The Dangers of Misappropriation: Misusing Martin Luther King, Jr.'s Legacy to Prove the Colorblind Thesis," Michigan Journal of Race \& Law, 2, I (1996), 1 о I-30.

${ }^{69}$ Jana Weiss, "Remember, Celebrate, and Forget? The Martin Luther King Day and the Pitfalls of Civil Religion," Journal of American Studies, 53, 2 (May 2019), 428-48, 432.

${ }^{70}$ Ward, Martin Luther King in Newcastle upon Tyne, 14. A recent exception is Sokol, The Heavens Might Crack. See also Alan Rice, Creating Memorials, Building Identities: The Politics of Memory in the Black Atlantic (Liverpool: Liverpool University Press, 2010).

${ }^{71}$ President Ronald Reagan quoted in Peter Goldman, "Dr. Kins Last Victory," Newsweek, 27 Jan. $1986,16$. 
King's words are now being used "to mean that white people should not be judged on the colour of their skin. That the power of whiteness as a race should not be judged." 72

In the 2018 paperback edition of her book, Eddo-Lodge reflected on its initial success and the conversations it provoked. Despite quoting King's 1963 "Letter from Birmingham Jail" at length in her original text to illustrate King's "grave disappointment with the white moderate ... more devoted to 'order' than to justice," Eddo-Lodge was met with further declarations from whites that "Martin Luther King Junior would never approve of [her] work." 73 Using a reductive, highly selective rendering of King's legacy to admonish the work and viewpoint of one of the most influential black voices in modern Britain, Eddo-Lodge's critics demonstrate just how readily King's legacy is coopted by conscious and unconscious defenders of white privilege on both sides of the Atlantic. British historian David Olusoga, himself of mixed racial heritage, describes Eddo-Lodge's book as "a retreat, a place of greater safety, where black people go for confirmation that their lived experiences are not a fantasy, a place they go in an effort to remain sane." ${ }^{44}$ That white critics repeatedly used King's decontextualized and dimly understood words to challenge the significance of such a profound and insightful piece of work demonstrates that how King is taught has enormous political ramifications beyond the US.

Further complicating this issue are complaints from many black commentators who echo Eddo-Lodge's concern that attempts to acknowledge black culture within British schools are often disproportionately centred on the African American experience. "An American-centric understanding of black history and identity makes Black History Month in the UK something like looking into a broken mirror," wrote Yomi Adegoke in The Guardian in October 2017. "You see yourself reflected within its fragments and the shards create a picture, though the whole thing is distorted." British children are more likely to learn about the Black Panther Party of Oakland, California than about South London's Black British Panthers, Adegoke continued, reflecting a wider critique of Britain's education system and its failure to educate students, black and white alike, on the legacy of slavery, colonialism,

${ }^{72}$ Reni Eddo-Lodge, Why I'm No Longer Talking to White People about Race (London: Bloomsbury, 2018), 28, I, 100-1, original emphasis.

${ }^{73}$ Ibid., $23 \mathrm{I}-32$.

${ }^{74}$ David Olusoga, "We Risk Losing Slices of Our Past if We Don't Root Out Racism in Our Universities," The Guardian, 2 I Oct. 20 I 8, at www.theguardian.com/commentisfree/20 I 8/ $\mathrm{oct} / 2 \mathrm{I} /$ we-risk-losing-slices-of-our-history-if-we-dont-root-out-racism-in-our-unversities, accessed 26 May 2020. 
and racism in modern Britain.75 "Personal engagement is much more likely when the students are themselves encouraged through history teaching to have a sense of their own personal identity and their place in the world," the Historical Association, the UK's leading historical charity, reported in 2007, while Nardia Foster has condemned how British schools often account for "black history" purely through the American civil rights movement. ${ }^{76}$ Perhaps most alarmingly, the Historical Association also noted, "In an all-white school, little black history may be taught at all on the grounds that there are no black pupils to whom it would be relevant." 77

In the wake of such concerns, addressing the misrepresentation of Martin Luther King Jr. in British schools may appear incidental, secondary to a more urgent debate over how to teach more and better black British history. When reflecting on how little she knew of black British history, Reni Eddo-Lodge writes of being "kept ignorant."”78 Without question, black British history and culture deserve a much more conspicuous place in the UK school curriculum, as they do in the media and public life. The erasure, or marginalization, of that history contributes to the kind of mystified or distorted history that, as James Loewen points out, "usually signifies a continuing injustice in the present, like racism." 79 Recent scandals involving the UK government's shocking mistreatment of the Windrush generation are testament to what April-Louise Pennant and Nando Sigona have called a "contested history of settlement, integration and exclusion" in which the rights and claims to "Britishness" of nonwhites are routinely questioned and sometimes denied. As Pennant and Sigona argue, the fact that the seventieth anniversary of the Empire Windrush's 1948 arrival from the Caribbean coincided with the deportation or detention of some of those who had arrived as British subjects and citizens decades ago, plus news that the Black Cultural Archive (which stands in Windrush Square, Brixton) faced closure due to lack of funding, "calls into question how much their

75 Yomi Adegoke, "It's Black History Month-and at Last We're Celebrating British Heroes," The Guardian, 17 Oct. 2017, at www.theguardian.com/commentisfree/2017/ oct/I6/black-history-month-british-culture-identity?CMP=share_btn_tw, accessed 28 Nov. 2017.

${ }^{66}$ The Historical Association, T.E.A.C.H.: Teaching Emotive and Controversial History, 3-19 (London: The Historical Association, 2007), 4; Nardia Foster, Out of Slavery: Learning about the History of British Black Caribbean People (Bristol: Redcliffe, 2004), 6.

77 The Historical Association, I 5. This reflects the SPLC's findings from the US, in which southern states, and those with large African American populations, tended to require more formal learning about the civil rights movement.

${ }^{78}$ Eddo-Lodge, 54.

79 James Loewen, "Preface: Lies My Teacher Told Me in the Age of Alternative Facts," in Loewen, Lies My Teacher Told Me (New York: The New Press, 20 I8), xi-xx, xx. 
presence, sacrifices and contributions are valued in Britain." ${ }^{\circ \circ}$ Citing Britain's "bout of amnesia," seventy years after "plead[ing] with its Commonwealth subjects to come to work and rebuild the country," Pennant and Sigona laid blame squarely on the inadequacies of the curriculum. "It's very rare that the contributions and histories of black people in Britain - which go back way further than 1948 - are incorporated or acknowledged within the curriculum," they write, noting that the arrival of the Empire Windrush was only introduced to (non-compulsory) history specifications in 2013. Even then, to focus on the arrival of the Windrush implies that Britain was exclusively white before 1948 and that those on board were overwhelmingly welcomed, rather than being, in many cases, the targets of racist abuse and discrimination. ${ }^{81}$

Official interest in issues of race in Britain's schools has traditionally focussed on rectifying alleged attainment gaps among students from different racial groups, rather than addressing the inadequacies of curriculum content. Thus Kehinde Andrews criticizes policymakers for "embracing the idea that it was the children who were "underachieving'." ${ }_{22}$ The UK Black Supplementary Schools Movement, which has provided additional education at the grass roots since the 1960 s, reflects this frustration. Founded to promote pride in and awareness of black history and culture, Black Supplementary Schools simultaneously help students "to succeed using the tools and

$8 \circ$ April-Louise Pennant and Nando Sigona, "Black History Is Still Largely Ignored, 70 Years after Empire Windrush Reached Britain," The Conversation, 2 I June 2018 , at https://theconversation.com/black-history-is-still-largely-ignored-70-years-after-empire-windrush-

reached-britain-98431, accessed 27 June 2018. In December 2018 the BCA received a $£_{200,000}$ interim payment from the Department for Digital, Culture, Media \& Sport after more than 100 Members of Parliament signed a letter urging the government to commit funds to the archive, which had received Heritage Lottery Funding since 2014. Sally Weale, "London's Black Cultural Archives get $£_{200,000}$ Stopgap Funding for Survival," The Guardian, I 3 Dec. 2018, at www.theguardian.com/uk-news/2018/dec/13/ london-black-cultural-archives-gets-thousands-stop-gap-funding-for-survival-heritage,

accessed 27 June 2019. The significance of the archive was made clear when it emerged that the Home Office had destroyed the landing cards of thousands of Commonwealth migrants in 2009, thus eradicating the evidence of their legal arrival in Britain between I947 and 197I. The BCA argued that such documents should have been passed on to them when they were no longer "needed" by the central government. "BCA exists to ensure the preservation of this history," it announced, "as our remit is to preserve the narratives of the people." Quoted in Eleanor Rose, "Black Cultural Archives Urge Government to Hand Over Important Documents to Avoid Second Windrush Fiasco, Bosses Claim," Evening Standard, 20 April 2018 , at www.standard.co.uk/news/uk/black-cultural-archives-urge-government-to-hand-over-important-documents-to-avoid-second-windrush-a3 8 I $908 \mathrm{I}$.html, accessed 8 Nov. 2018.

${ }^{81}$ Pennant and Sigona.

82 Kehinde Andrews, "Why Britain's Schools Are Failing to Tackle Racism," The Guardian, I2 Aug. 2015, at www.theguardian.com/commentisfree/2015/aug/r 2/racism-schools-government-reforms-targets, accessed 28 Nov. 2017. 
assessment strategies they would encounter in mainstream education." 83 Andrews notes that the teaching of black history within these schools has always drawn on a "[d]iasporic politics that connects the students and teachers to an international politics and identity." Andrews names Marcus Garvey, Malcolm X, and Nelson and Winnie Mandela as key figures for the Supplementary Schools, concluding that "the general teaching of black history was focussed on the global Diaspora and how those experiences influenced Britain." 84

Perhaps, then, the problem is less that there is too much attention given to King and the African American freedom struggle in mainstream British schools, and rather that these topics are rarely presented in any meaningful way alongside equivalent - and often interconnected-struggles in the UK, the British Empire, or, later, the Commonwealth. While many of the modular options available to secondary students in the UK theoretically offer considerable opportunities to discuss the contemporary importance of historical topics and issues, the Historical Association reported that the vast majority "do not require any connection [to be] made with the present." 85 The US civil rights movement too often becomes "the story of the struggle against racism," Eddo-Lodge writes, "eclipsing the black British story so much that we convince ourselves that Britain has never had a problem with race." ${ }^{86}$ Racism is therefore projected as a peculiarly American problem, evident still in staggering inequality, mass incarceration, debates over Confederate monuments and, most recently, widespread uprisings in response to continued police brutality and a presidency that is openly hostile to minorities. Yet there are clearly comparable and concurrent flashpoints throughout British history and contemporary politics that could and should be better probed in classrooms across the UK. To do so would encourage students to draw links between global manifestations of racism, and the legacies of slavery throughout the Atlantic World; it would challenge assumptions that "Britain does not have the same deep rooted problems as the US did," as one British university student put it when quizzed about the value of studying the African American freedom struggle. ${ }^{87}$

${ }^{8}$ Kehinde Andrews, Resisting Racism: Race, Inequality, and the Black Supplementary School Movement (London: Institute of Education Press, 2013), i 8.

${ }^{84}$ Kehinde Andrews, "The Problem of Political Blackness: Lessons from the Black Supplementary School Movement," Ethnic and Racial Studies, 39, I I (2016), 2060-78, 207 I.

85 The Historical Association, I3, added emphasis.

${ }^{86}$ Eddo-Lodge, 55, added emphasis.

${ }^{87}$ Here, a student was answering the question "What relevance do you think studying MLK and/or the civil rights movement may have for modern Britain?" For further information on this informal, anonymous survey, see the affiliation note. 
None of the "standard" curricula or textbooks consulted for this article made any attempt to link King or the African American civil rights movement to events in the UK during the I950s and 1960s - a pivotal period in the development of modern Britain that shaped its racial present. ${ }^{88}$ This ignores transatlantic visits by high-profile African American leaders including King and Malcolm X, but also the importance of transnational activist networks and exchanges of ideas in the development of British antiracism, and civil rights and black power groups. While these groups often adopted the rhetoric, tactics, and symbolism of the American groups that inspired them, their composition and priorities reflected the specific issues they faced in the UK, as well as British conceptions of what it meant to be "black" at that time - a term that often encompassed those of Indian or Pakistani origin as well as those from the West Indies and Africa. "America was not the starting point of this exchange, nor Britain the final destination," Stephen Tuck writes. ${ }^{89}$ Rooting his analysis in Malcolm X's 1964 speech at the University of Oxford, Tuck concludes that the British activists and organizations that conversed with, invited and celebrated African American civil rights and black power leaders invite us to "de-center the United States in the study of the modern global anti-racist struggle." 9 In this context, the imperative is not to omit study of the African American freedom struggle, but rather to place it within a wider story of racial discrimination and efforts to resist it throughout the world, including the UK. While the distinctiveness of civil and human rights struggles in various locales at particular historic moments needs to be acknowledged, they did not happen in isolation. Their intertwined histories help shed light on the underlying structural coordinates of racial, gender, economic, and many other kinds of social inequality around the world and on the diverse movements that have emerged to confront them.

Opportunities for teachers to explore these connections exist, but the resources to assist them are sparse. The Black Curriculum syllabus provides teacher training and materials on twelve varied topics, from the influence of Caribbean music in the UK to contemporary issues around migration and deportation. ${ }^{91}$ Assembly plans developed for Black History Month 2019 by Historians of the Twentieth Century United States (HOTCUS) showcase

${ }^{88}$ In a rare and fleeting reference to the influence of African anticolonial struggles on King, Sanders, Civil Rights, 73, notes that "African Americans were fascinated by the emergence of independent African nations," and that King attended independence celebrations in Ghana, along with Vice President Richard Nixon, Adam Clayton Powell, and A. Philip Randolph.

89 Stephen Tuck, "Malcolm X's Visit to Oxford University: US Civil Rights, Black Britain, and the Special Relationship on Race," American Historical Review, I I 8, I (Feb. 2013), 76-103, 82.

$9^{\circ}$ Ibid., 80. $\quad{ }^{11}$ See www.theblackcurriculum.com/ourcurriculum, accessed 3 June 2020. 
King's visit to Newcastle, as well as connections between the Montgomery bus boycott, the March on Washington and the Bristol bus boycott. ${ }^{22} \mathrm{~A}$ teaching pack created with schoolteachers as part of Freedom City 2017 provides materials that illuminate, rather than obscure, King's radicalism and encourage students to interrogate its significance in modern Britain. ${ }^{93}$ Older online resources from the UK National Archives document British responses to the African American civil rights movement, including telegrams sent from the British Embassy in Washington DC, advising politicians in London of the situation in the American South. Documents available date from 1957 until King's assassination in 1968 , providing a valuable window into British diplomatic responses to the unfolding racial crisis in the US. ${ }^{94}$ As well as demonstrating global connections, these resources encourage engagement with what Loewen calls "the raw materials of history" - the primary sources from which textbooks so often insulate students. ${ }^{95}$ Each document is supplemented with discussion questions or exercises for students to complete, some of which encourage students to write newspaper reports from a British perspective utilizing the information in the sources. Not replicated in textbooks or curricula, only a highly proactive teacher or student would be likely to find and utilize these invaluable resources.

The teaching materials on King most readily available to UK teachers predominantly exist in history and religious studies curricula and textbooks, augmented by resources created by charities and individual teachers, some of which are available for download via the TES (previously known as the Times Educational Supplement) website. Like the National Archives resources, these materials are not necessarily reflective of official educational policy, but they offer further frameworks for understanding King's significance and legacy in UK schools. Indeed, the extent to which these materials reflect or diverge from the dominant presentation of King in textbooks and curricula is indicative of the various forces that compete to shape King's legacy in Britain. Educational antiracism charities, for example, use King as a springboard for discussions of race in contemporary society, and are often more invested in an ongoing dialogue about equality and social justice than are "standard" history texts. For example, True Tube, a BAFTA-winning media charity, offers an assembly plan for schools wishing to mark Martin Luther King Day in the UK, which "outlines a brief history of Martin Luther

${ }^{2}$ See https://hotcus.org.uk/diversity-and-inclusion/black-history-month-assembly-materials, accessed 2 Oct. 2019.

93 See https://research.ncl.ac.uk/martinlutherking/activities/mlkinuk, accessed 26 May 2020.

${ }^{94}$ See "Martin Luther King and the Civil Rights Movement," Heroes and Villains, The National Archives, at www.nationalarchives.gov.uk/education/heroesvillains/g6, accessed 27 June 2018.

95 Loewen, Lies My Teacher Told Me (1996), i6. 
King's work and asks if discrimination still exists in British society." Concluding with a video that explores racial profiling, this assembly also examines the 1994 murder of Stephen Lawrence and the findings of the subsequent MacPherson inquiry, which found institutional racism at the heart of London's Metropolitan Police. ${ }^{96}$ These resources use King's legacy to explore enduring problems of race in Britain, and to encourage students to offer their voices for change.

Show Racism the Red Card (SRTRC), another antiracism charity, coordinated screenings of the 2014 film Selma, Ava DuVernay's depiction of the I 965 voting rights campaign in Selma, Alabama, as part of the Into Film Festival, which enables students and teachers to engage with cinema in new and educational ways. While some lucky school groups attended special screenings to supplement their studies and stimulate debate, additional resources were published on the Into Film website for use by any teachers or schools. ${ }^{97}$ As well as prompting students to think about the contemporary implications and legacies of the events depicted in Selma, the resources encourage cinema literacy, urging students to consider how King is presented, not simply in terms of characterization, dialogue and plotline, but also through music, camera angles, and setting..$^{8}$ As such, these resources encourage students to analyse and critique cinematic representations of history, and to question the decisions and underlying power dynamics that profoundly shape the creation of popular memory and memorialization - key components of contemporary historiographical debate and valuable tools for an engaged citizenry. Materials and initiatives like this, however, are very much the exception.

\section{V}

Academics seldom engage with the specifics of what is being taught in schools, although university instructors often spend a good deal of time filling in historical gaps, correcting factual errors, and exposing interpretive oversimplifications that their students bring with them from school. That is important, necessary, and perhaps inevitable work, given the pressures on teachers and the difficulties involved in keeping up with the literature in their field.

${ }_{96}^{6}$ True Tube, Stop and Search Me, Film and Assembly Plan (2010), at www.truetube.co.uk/ film/stop-and-search-me?tab=film, accessed 22 Nov. 2018.

97 State-funded schools can join the Into Film Club for free, where they have access to thousands of titles and related-resources. For Selma-specific resources see www.intofilm.org/ resources/ıo. For an account of the SRTRC screenings of Selma see www.theredcard. org/news/2015/1 I/04/selma-screening, both accessed 23 July 2018.

${ }^{8}$ Into Film, "Civil Rights on Film: Selma Assembly," at www.intofilm.org/resources/ o; Into Film, "Selma: Film Guide," at https://www.intofilm.org/resources/1 87, both accessed 23 July 2018. 
Rather than seeing this as a necessary evil, or as an additional chore in their own busy schedules, however, university teachers might do well to think of this more positively. They are, after all, uniquely positioned to bridge the gap between what is popular and taught in schools and the latest scholarship.

That historical study has become increasingly politicized in recent years should raise significant questions for historians of the US working in the UK, as well as for those interested in memory and race in a British context. It is encouraging to see that, even as teachers face more restrictions on their time and resources, they still elect to mark King's life and legacy in assemblies and other settings where they have more freedom. King's legacy and celebrity offer a significant opportunity to introduce students to struggles for racial justice in Britain and its empire, documenting how transnational networks of solidarity were fostered against historic patterns of prejudice and discrimination. King's life and legacy are also profoundly important in their own right, as demonstrated by the ways in which selective, decontextualized soundbites from King's career have been used to question and undermine the work of prominent black British authors interested in opening up difficult national conversations on race. In short, King's legacies matter outside the United States, and, as political and ideological battles rage over how best to define, appropriate, and deploy his memory, academic historians would do well to work with those involved with public education, to offer better, more nuanced, and more internationally relevant introductions to King, the African American freedom struggle, and the global fight for human rights and social justice to which they contributed.

Ultimately, then, this article poses a range of interlocking questions about how racial histories are and might be taught and presented to the British public, including highly impressionable schoolchildren growing up in a multicultural, globally connected society. The challenge is to teach King and the modern US freedom struggle better and more comprehensively, but it is also to provide histories of race and racism that remain sensitive to the distinctiveness of particular locales, groups, institutions, and contexts, while also being attentive to transnational forces of oppression, solidarity, and resistance. These are important challenges. Perhaps counterintuitively, however, given that the substantive focus of this article is on how a more nuanced, explicitly transnational approach to King and the civil rights movement can illuminate the history of British race relations, the biggest challenge is to promote the teaching of black British history in its own right and on its own terms. Instead of relying on the African American freedom struggle to provide an all-too-rare rare glimpse of nonwhite history in British classrooms, there should be proper coverage of black British history-ideally a coverage that explores its manifold connections to other global histories, including, but not limited to, the African American experience. 
The political and social stakes of this project are extraordinarily high. As David Olusoga has summarized, "with black history and black people largely expunged from the mainstream narrative of British history, we have been left with a distorted and diminished vision of our national past." 99 This erasure, much like the elision of King's radicalism and a preoccupation with his charismatic leadership that neglects the ideas, rhetoric, influences, and networks that enabled that leadership, fosters dangerously superficial, parochial, and misleading understandings of the past. Too often, on both sides of the Atlantic, the "legions of half-truths, prejudices, and propaganda" that King decried have been pressed into the service of reactionary, racially circumscribed, national mythologies that privilege and unite some people, while denigrating and excluding others. ${ }^{100}$

\section{SUPPLEMENTARY MATERIAL}

To view supplementary material for this article, please visit https://doi.org/ ı०. I $017 /$ So02 I 875820000742 .

\section{AUTHOR BIOGRAPHIES}

Megan Hunt is Teaching Fellow in American History at the University of Edinburgh. She is working on her first monograph, Southern by the Grace of God: Religion, Race, and Civil Rights in Hollywood's South, having previously published on films such as Selma, Mississippi Burning, and The Help. Research for this article was supported by Freedom City 2017, a city-wide commemoration of Newcastle University's award of an honorary doctorate to Martin Luther King in November 1967.

Benjamin Houston is Senior Lecturer at Newcastle University. He is author of The Nashville Way: Racial Etiquette and the Struggle for Social Justice in a Southern City (2012) and recent articles in Slavery \& Abolition and Public Historian.

Brian Ward is Professor in American Studies at Northumbria University. He has published widely on the US South, African American history, popular music, and the Atlantic World. His most recent books are AઐR Pioneers: Architects of American Roots Music on Record (2018: co-authored with Patrick Huber) and Martin Luther King in Newcastle upon Tyne: The African American Freedom Struggle and Race Relations in the North East of England (2017).

Nick Megoran is Professor of Political Geography at Newcastle University and co-convenor of the Martin Luther King Peace Committee. He is the author of numerous books and articles on peace, nonviolence, and education.

99 David Olusoga, Black and British: A Forgotten History (London: Macmillan, 2016), 25.

${ }^{100}$ King, "The Purpose of Education." 